\title{
Measurement of phenylalanine in routine care of phenylketonuric children
}

\author{
N. R. BELTON, J. D. CROMBIE, S. P. ROBINS, RHONA STEPHEN, \\ and J. W. FARQUHAR \\ From the Department of Child Life and Health, University of Edinburgh; the Royal Hospital for Sick Children; and \\ the Simpson Memorial Maternity Pavilion, The Royal Infirmary of Edinburgh, Edinburgh
}

Belton, N. R., Crombie, J. D., Robins, S. P., Stephen, R., and Farquhar, J. W. (1973). Archives of Disease in Childhood, 48, 472. Measurement of phenylalanine in routine care of phenylketonuric children. Fluorimetry, paper and column chromatography, and bacterial inhibition assay have been compared in the quantitation of serum or blood phenylalanine at levels ranging from 1 to over $30 \mathrm{mg} / 100 \mathrm{ml}$. Special attention was paid to levels of $2 \mathrm{mg}$ or less and to those in excess of $20 \mathrm{mg} / 100 \mathrm{ml}$, since these have therapeutic implications. Bacterial inhibition assay, under routine conditions, tended to read low or not at all at $2 \mathrm{mg}$ or less, and to read high above $20 \mathrm{mg} / 100 \mathrm{ml}$ so that it 'failed safe' under such conditions. Paper chromatography was shown to be a simple, rapid, and economic method of getting accurate results at all levels in the range examined.

The accuracy with which laboratory methods, already tried and approved in research conditions, are routinely applied may vary widely in different hospitals and possibly even in different centres. This was convincingly shown in comparisons made by Wootton and King (1953), and played a part in the human failure involved in the mass screening of babies' urine with Phenistix for phenylketonuria (Farquhar, Kansas, and Tait, 1962). For more obvious reasons different methods, even when used in the same laboratory, may yield different values, for example for phenylalanine in the same blood specimen. Such common variations imply that blood containing precisely 2 or $20 \mathrm{mg}$ of phenylalanine per $100 \mathrm{ml}$ will not be reported consistently by all methods or by all laboratories, and indeed the range of reported values may be surprising.

In the long term, however, in phenylketonuria accuracy and reproducibility of results by one method and comparability with results by other methods are important, e.g. in the complicated and perhaps impossible task of relating final intelligence to the standard of control over a period of years (mean blood phenylalanine, range, and SD). Thus a laboratory or method providing false high values may mislead the physician of a well-preserved patient into believing and teaching that strict

Received 20 October 1972. control is unnecessary, while false low values may provoke equally false conclusions in patients with some degree of mental subnormality.

In the immediate management of the case, and for reasons which even now may be no more than clinical suspicion, a reported blood level of less than $2 \mathrm{mg} / 100 \mathrm{ml}$ causes the physician to increase the phenylalanine intake immediately, while a level above $20 \mathrm{mg} / 100 \mathrm{ml}$ in all clinics (and above $10 \mathrm{mg} / 100 \mathrm{ml}$ in some, including this one) prompts the prescription of a reduced daily amount.

\section{Nature of study}

The study was arranged to answer the following questions.

(1) Are the methods described below comparable around 5 to $10 \mathrm{mg} / 100 \mathrm{ml}$ in the hands of this group? The difference between these two levels may be unimportant.

(2) Can a method fail to detect levels less than $2 \mathrm{mg} / 100 \mathrm{ml}$ and so lead to continued harmful restriction of phenylalanine intake?

(3) Can a method underestimate high levels of phenylalanine and cause failure to restrict phenylalanine intake?

(4) Can a method overestimate high levels of phenylalanine and cause unnecessary restriction of phenylalanine intake? 


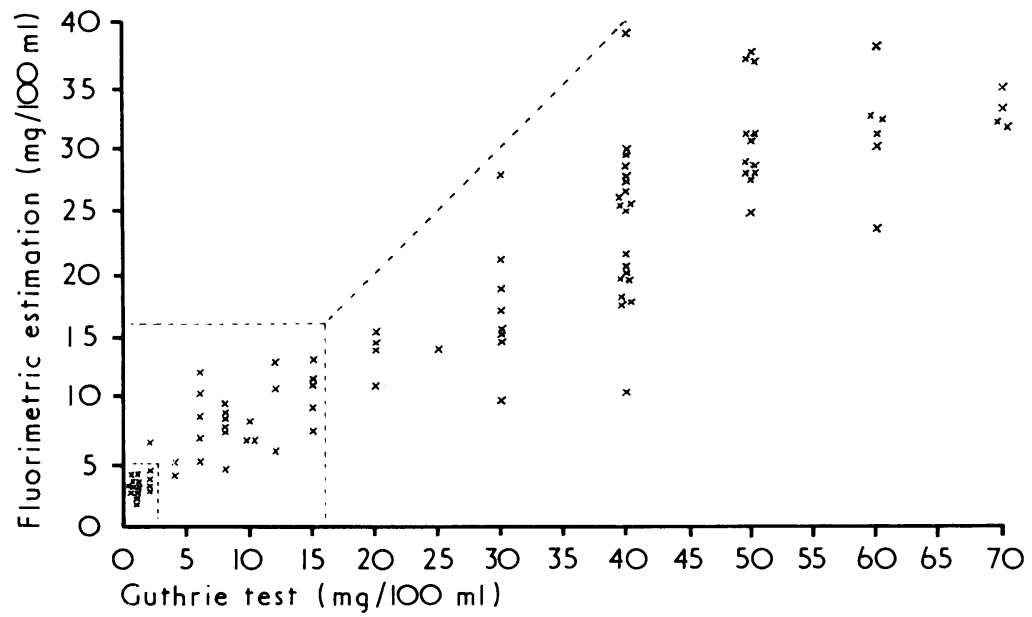

FIG. 1.-Comparison of phenylalanine estimation by fluorimetry and the Guthrie test.

(5) Can variation in the result of one blood specimen be caused by using whole blood or serum ?

\section{Methods}

In order to study a wide range of results, blood was obtained from patients whose condition was acceptably controlled and from the same patients at time intervals throughout phenylalanine loading tests. Venous samples were taken, were transferred to tubes, and also dripped from the intravenous needle onto the printed rings of Guthrie test absorbent paper (eliminating the common error caused by smudging layers of blood from skin-prick onto paper).

The blood specimens in tubes were centrifuged as soon as possible after withdrawal, usually within a few minutes, and the serum was frozen.

The Guthrie test was performed by a laboratory which has an excellent record in detecting hyperphenylalaninaemia, but which was not informed that comparisons were being made.

Phenylalanine was estimated in serum (a) fluorimetrically using an EIL 27A.2 fluorimeter and following the Wong, O'Flynn, and Inouye (1964) modification of the spectrophotometric method of McCaman and Robins (1962); (b) by one-dimensional ascending paper chromatography using a $12: 3: 5$ butanolacetic acidwater solvent system. The equivalent of $50 \mu \mathrm{l}$ serum were spotted onto Whatman No. 1 paper after initial deproteinization with ethanol. Sample spots were cut out and eluted in $2.0 \mathrm{ml} 50 \%$ ethanol and compared colorimetrically with standards run simultaneously throughout the method; (c) in 6 samples by ion exchange chromatography using a Technicon amino acid analyser (Cockburn, Blagden, and Robins, 1971).

On one occasion phenylalanine was estimated fluorimetrically on whole blood, plasma, serum, and red cells from a single sample of venous blood.

\section{Results}

Fig. 1 shows that though there was good agreement between fluorimetric estimations of phenylalanine and the Guthrie test between 5 and 15 $\mathrm{mg} / 100 \mathrm{ml}$, above $15 \mathrm{mg} / 100 \mathrm{ml}$ in every case the Guthrie test gave a higher result with the difference being more than $10 \mathrm{mg} / 100 \mathrm{ml}$ in most cases. Conversely, every Guthrie test result which was recorded as less than $2 \mathrm{mg} / 100 \mathrm{ml}$ showed levels of $2 \mathrm{mg} / 100 \mathrm{ml}$ or greater by fluorimetry, and all Guthrie test results reported as $2 \mathrm{mg} / 100 \mathrm{ml}$ had on fluorimetry values of $3 \mathrm{mg} / 100 \mathrm{ml}$ or greater. That is, results of $2 \mathrm{mg} / 100 \mathrm{ml}$ or below by the Guthrie test were consistently lower than by fluorimetry. These findings are summarized in Table I.

\section{TABLE I}

Comparison of very low phenylalanine results by Guthrie test with values obtained by fluorimetry and paper chromatography

\begin{tabular}{c|c|c|c}
\hline $\begin{array}{c}\text { Guthrie } \\
\text { test }\end{array}$ & $\begin{array}{c}\text { No. of } \\
\text { results }\end{array}$ & Fluorimetry & $\begin{array}{c}\text { Paper } \\
\text { chromatography }\end{array}$ \\
\hline$<2$ & 12 & $\begin{array}{c}3 \cdot 08 \pm 0 \cdot 65 \\
(2 \cdot 9-4 \cdot 1)\end{array}$ & $\begin{array}{c}2 \cdot 36 \pm 1 \cdot 31 \\
(1 \cdot 0-4 \cdot 5)\end{array}$ \\
2 & 6 & $\begin{array}{c}4 \cdot 15 \pm 1 \cdot 29 \\
(3 \cdot 0-6 \cdot 6)\end{array}$ & $\begin{array}{c}3 \cdot 60 \pm 2 \cdot 60 \\
(1 \cdot 5-8 \cdot 0)\end{array}$ \\
\hline
\end{tabular}

Note: All values are in $\mathrm{mg} / 100 \mathrm{ml}$. All results for fluorimetry and paper chromatography show the mean values $\pm S D$ with the extreme ranges in parentheses.

A similar pattern was found in the comparisons between paper chromatography and the Guthrie 


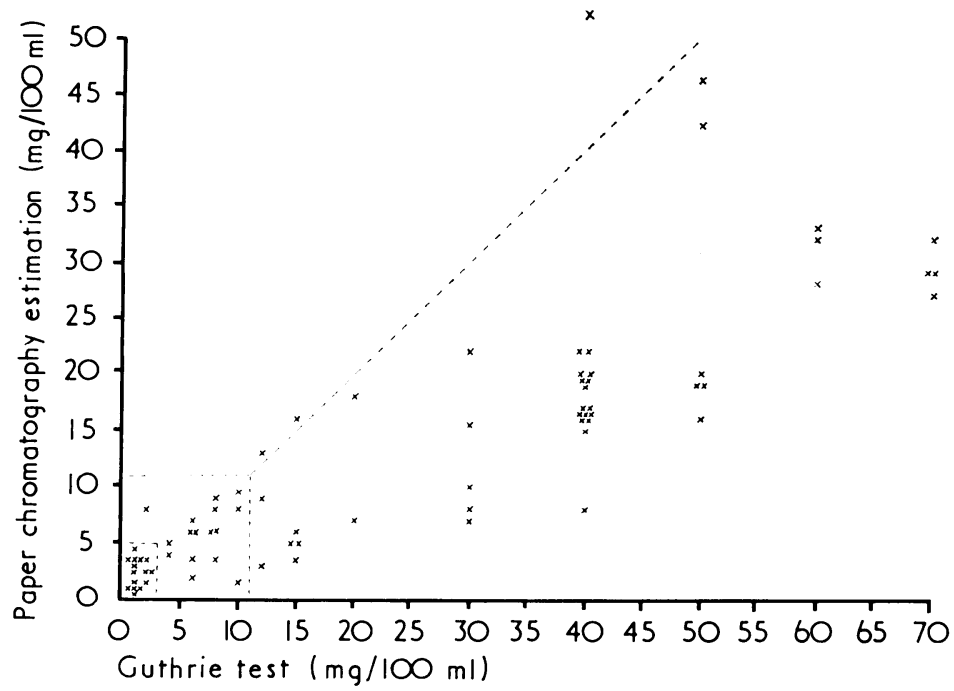

FIG. 2.-Comparison of phenylalanine estimation by paper chromatography and the Guthrie test.

test (Fig. 2). In most cases where the Guthrie test result was between 4 and $10 \mathrm{mg} / 100 \mathrm{ml}$ there was good agreement with the paper chromatography value. Above $10 \mathrm{mg} / 100 \mathrm{ml}$, in all cases but two, the Guthrie test gave a higher value than that found in paper chromatography with the difference being $20 \mathrm{mg} / 100 \mathrm{ml}$ in most instances. However, Guthrie test results of $2 \mathrm{mg} / 100 \mathrm{ml}$ and below were lower than those by paper chromatography (Table I).

Over the whole range, fluorimetry and paper chromatography correlated better with each other than they did with the Guthrie test. Fluorimetric results tended to be slightly higher than paper chromatography and the difference was in general greater above about $22 \mathrm{mg} / 100 \mathrm{ml}$ (Fig. 3).

A comparison of estimations of phenylalanine by the Guthrie test, fluorimetry, column chromatography, and paper chromatography is shown in Table II. In virtually all cases the relation of the results was in the order given, with the

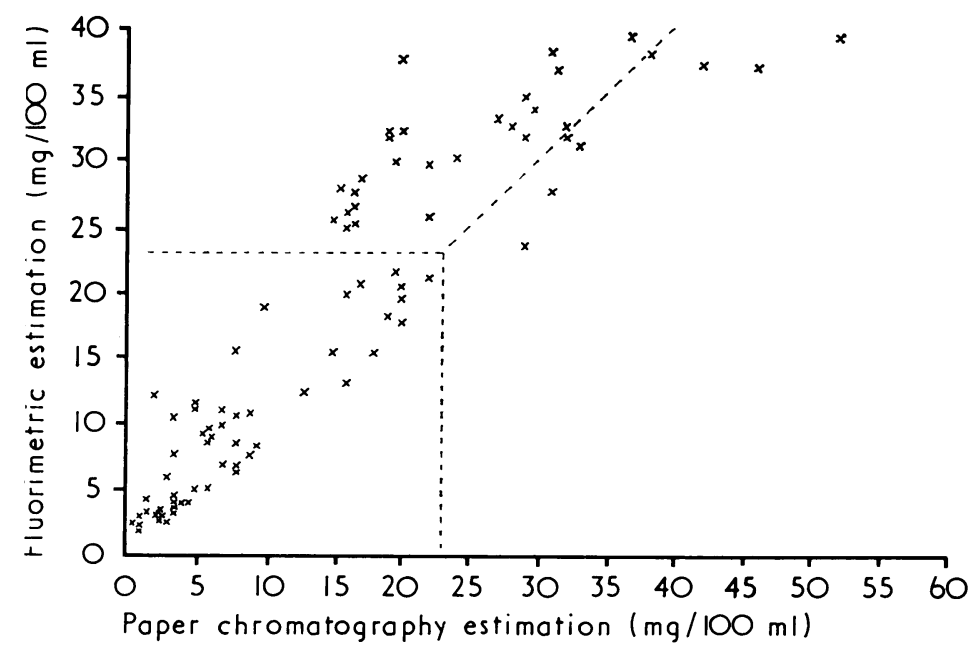

FIG. 3.-Comparison of phenylalanine estimation by fuorimetry and paper chromatography. 
TABLE II

Comparison of phenylalanine estimation in blood serum by 4 different methods

\begin{tabular}{c|c|c|c}
\hline Blood & \multicolumn{3}{|c}{ Serum } \\
\hline $\begin{array}{c}\text { Guthrie } \\
\text { test }\end{array}$ & Fluorimetry & $\begin{array}{c}\text { Column } \\
\text { chromatography }\end{array}$ & $\begin{array}{c}\text { Paper } \\
\text { chromatography }\end{array}$ \\
\cline { 2 - 3 } 15 & $11 \cdot 6$ & $6 \cdot 2$ & $5 \cdot 0$ \\
30 & $27 \cdot 8$ & $18 \cdot 7$ & $15 \cdot 5$ \\
40 & $26 \cdot 4$ & $18 \cdot 6$ & $16 \cdot 5$ \\
40 & $27 \cdot 6$ & $20 \cdot 8$ & $16 \cdot 5$ \\
40 & $28 \cdot 5$ & $19 \cdot 1$ & $17 \cdot 0$ \\
60 & $31 \cdot 0$ & $21 \cdot 6$ & $33 \cdot 0$ \\
\hline
\end{tabular}

Note: All values are in $\mathrm{mg} / 100 \mathrm{ml}$.

Guthrie test being the highest and paper chromatography the lowest. The good correlation between column chromatography and paper chromatography for 5 of the 6 samples shows the reliability of paper chromatography.

The comparison between phenylalanine estimations by fluorimetry on whole blood, serum, plasma, and red cells from a single specimen are shown in Table III. The red cells contained the highest

\section{TABLE III}

Comparison of phenylalanine in whole blood, red cells, plasma, and serum

\begin{tabular}{|c|c|}
\hline $\begin{array}{l}\text { Phenylalanine in } \\
\text { Whole blood } \\
\text { Red cells } \\
\text { Plasma } \\
\text { Serum }\end{array}$ & $\begin{array}{l}25 \cdot 0 \mathrm{mg} / 100 \mathrm{ml} \\
29 \cdot 7 \mathrm{mg} / 100 \mathrm{ml} \\
22 \cdot 1 \mathrm{mg} / 100 \mathrm{ml} \\
22 \cdot 0 \mathrm{mg} / 100 \mathrm{ml}\end{array}$ \\
\hline
\end{tabular}

Calculation:

Red cells $29.7 \mathrm{mg} / 100 \mathrm{ml} \times 38.5 \%=11.4 \mathrm{mg} / 100 \mathrm{ml}$ Plasma $22.1 \mathrm{mg} / 100 \mathrm{ml} \times 61.5 \%=13.6 \mathrm{mg} / 100 \mathrm{ml}$ Total $=25.0 \mathrm{mg} / 100 \mathrm{ml}$ and this is equivalent to the whole blood estimated value of $25.0 \mathrm{mg} / 100 \mathrm{ml}$

concentration of phenylalanine $(29.7 \mathrm{mg} / 100 \mathrm{ml})$ while the whole blood result, $25 \cdot 0 \mathrm{mg} / 100 \mathrm{ml}$, was higher than those of plasma $22 \cdot 1 \mathrm{mg} / 100 \mathrm{ml}$ and serum $22 \cdot 0 \mathrm{mg} / 100 \mathrm{ml}$, which were almost identical. As shown in Table III using the determined haematocrit value of $38.5 \%$, the estimated values for whole blood and plasma correlated extremely well with the whole blood result.
The result of this experiment may not be valid for all blood samples, but if it were so, it would in part explain why the Guthrie test on whole blood gives higher values than serum or plasma determinations by other methods.

\section{Conclusions}

(1) The Guthrie test may underestimate the blood phenylalanine concentration at very low levels but is thus not likely to overlook undesirably low values.

(2) Fluorimetry and paper chromatography are more accurate indices of serum phenylalanine concentration at these very low levels.

(3) The Guthrie test may overestimate phenylalanine concentration at 15 to $20 \mathrm{mg} / 100 \mathrm{ml}$ and above, and this could lead to unnecessary restriction of phenylalanine intake.

(4) The Guthrie test, fluorimetry, and paper chromatography are all roughly comparable and reliable at the 5 to $10 \mathrm{mg} / 100 \mathrm{ml}$ level.

(5) A greater concentration of phenylalanine in whole blood compared to plasma and serum may in part explain high Guthrie test results.

(6) Paper chromatography may be a simple, safe, and reliable routine technique for the estimation of serum phenylalanine in hospitals where more sophisticated methods are not available.

Thanks are due to Dr. John Stevenson and his staff who maintain the Guthrie test service for Scotland at Stobhill Hospital, Glasgow.

\section{REFERENCES}

Cockburn, F., Blagden, A., and Robins, S. P. (1971). Amino acid concentrations in human foetal fluids. In Automation in Analytical Chemistry: Technicon Symposium, London, 1969, p. 165. Technicon Instrument Company, Chertsey, Surrey. Farquhar, J. W., Kansas, E. T., and Tait, H. P. (1962). Problems of routine screening for phenylketonuria. Lancet, 2, 498.

McCaman, M. W., and Robins, E. (1962). Fluorimetric method for the determination of phenylalanine in serum. Fournal of Laboratory and Clinical Medicine, 59, 885.

Wong, P. W. K., O'Flynn, M. E., and Inouye, T. (1964). Micromethods for measuring phenylalanine and tyrosine in serum. Clinical Chemistry, 10, 1098.

Wootton, I. D. P., and King, E. J. (1953). Normal values for blood constituents: inter-hospital differences. Lancet, 1, 470.

Correspondence to Dr. J. W. Farquhar, Department of Child Life and Health, 17 Hatton Place, Edinburgh EH9 1UW. 